九州大学学術情報リポジトリ

Kyushu University Institutional Repository

\title{
Effect of Some Reductones on Protein Synthesis in vitro'
}

Tomita, Yoshifumi

Laboratory of Food Chemistry, Faculty of Agriculture, Kyushu University

Shinohara, Kazuki

Laboratory of Food Chemistry, Faculty of Agriculture, Kyushu University

Fujiki, Hiroaki

Laboratory of Food Chemistry, Faculty of Agriculture, Kyushu University

Murakami, Hiroki

Laboratory of Food Chemistry, Faculty of Agriculture, Kyushu University

他

https://doi.org/10.5109/23694

出版情報：九州大学大学院農学研究院紀要. 24 (1)，pp.37-48，1979-08. Kyushu University バージョン：

権利関係 : 
J. Fac. Agr., Kyushu Univ., 24 (1), 37-48 (1979)

\title{
Effect of Some Reductones on Protein Synthesis in vitro'
}

\author{
Yoshifumi Tomita ${ }^{2}$, Kazuki Shinohara, Hiroaki Fujiki ${ }^{3}$, \\ Hiroki Murakami and Hirohisa Omura ${ }^{1}$ \\ Laboratory of Food Chemistry, Faculty of Agriculture. \\ Kyushu University 46-09, Fukuoka 812
}

(Received April 16, 1979)

\begin{abstract}
Reductones such as ascorbic acid and 5-methyl-3,4-dihydroxytetrone (enediol), scorbamic acid (enaminol) and mercapto-hydroxycoumarine (thiolenol) degraded polysomes as well as ribosomal RNA in ribosome particles in vitro. They caused significant changes in amino acid incorporation by polysome and $\mathrm{pH} 5$ enzyme system or liver slices with endogenous RNA or poly $U$ as the messenger. The results suggested the possibility that reductones affect protein synthesis through the breakage of mRNA and rRNA and give some clues elucidating processes between DNA breakage and cytodifferentiation or cytoanomalization demonstrated as Yamafuji's effect.
\end{abstract}

\section{INTRODUCTION}

In the preceding study conducted on the basis of the ability of several reductones to break nucleic acids, it was confirmed that they brought about variation of the priming activity for DNA-primed DNA and RNA polymerases (Tomita et al., 1979). Since it was supposed that protein synthesis may be also influenced through nucleic acids synthesis, effect of reductones on the protein synthesizing system was then investigated in vitro, in relation to mutation of bacteria (Omura et al., 1978) or repression of growth of tumor cells by them (Yamafuji and Murakami, 1968; Yamafuji et al, 1970, 1971; Omura et al., 1974, 1975).

\section{MATERIALS AND METHODS}

\section{Chemicals}

Reductones employed include ascorbic acid (AsA),5-methyl-3,4-dihydroxytetrone (MDT), ascorbate-3-phosphate (AsA-3-P), scorbamic acid (ScA) and mercapto-hydroxycoumarine (HMC). They were same as those employed in the preceding study. ATP. GTP, poly U, phosphoenolpyruvate and pyruvate kina-

Studies on the Function of Reductones. Part 39.

Present address: Department of Public Health, School of Medicine, Kurume University, Kurume 830-91.

Present address: Institute of Food Technology, Meiji Seika Co. Ltd., Kawasaki 210.

Reprint request should be addressed to this author. 
se, type II were purchased from the Sigma Chemicals Co. L-(U-14 $\left.{ }^{14}\right)$-leucine $(324 \mathrm{mCi} / \mathrm{mmole}), \mathrm{L}-\left(\mathrm{U}-{ }^{14} \mathrm{C}\right)$-phenylalanine $(522 \mathrm{mCi} / \mathrm{mmole})$ and $\left(\mathrm{U}-{ }^{14} \mathrm{C}\right)$-protein hydrolysate $(57 \mathrm{mCi} /$ matom carbon) were obtained from the Radiochemical Center, Amersham.

\section{Ribosomes}

Preparation of ribosome fraction: Preparation of ribosomes was carried out principally according to Muramatsu (1972) with some modifications.

A male ddN mouse ( 4 to 5 weeks old) was killed by decapitation after starving on water for $24 \mathrm{hrs}$. The liver was immediately excised and homogenized in $3 \mathrm{ml}$ of $0.25 \mathrm{M}$ sucrose-TKM buffer $(50 \mathrm{mM}$ Tris buffer, pH 7.6-25 $\mathrm{mM} \mathrm{KCl}-5 \mathrm{mM} \mathrm{MgCl}_{2}$ ) per $1 \mathrm{~g}$ of liver with 10 strokes of a teflon homogenizer of Potter-Elvehjem type. The homogenate was centrifuged at $13,000 \mathrm{rpm}$ for $10 \mathrm{~min}$ to remove mitochondria or other cell debris. The supernatant, postmitochondria fraction, was further centrifuged at $40,000 \mathrm{rpm}$ for $60 \mathrm{~min}$ to obtain microsome pellet. To the suspension of the pellet in TKM buffer was added sodium deoxycholate to give a final concentration of 1.3 \% The solution was carefully placed on the layer of $0.5 \mathrm{M}$ sucrose-TKM buffer and centrifuged at $40,000 \mathrm{rpm}$ for $2.5 \mathrm{hrs}$ to wash the pellet. The precipitate was suspended in a small volume of TKM buffer and the insoluble part was removed by centrifugation at $4,000 \mathrm{rpm}$ for $5 \mathrm{~min}$. The supernatant was employed as a ribosome fraction for study. The absorption maximum and the minimum of the preparation was $258 \mathrm{~nm}$ and $236 \mathrm{~nm}$ respectively, and the ratio of the optical density at $280 \mathrm{~nm}$ to that at $260 \mathrm{~nm}\left(\mathrm{E}_{280} / \mathrm{E}_{260}\right)$ was 0.57 .

Treatment of ribosomes with reductones: The sample of the ribosomes (2. Omg $/ \mathrm{ml}$ ) was incubated with $5 \mathrm{mM}$ reductones with or without $50 \mu \mathrm{M} \mathrm{Cu}^{2+}$ in $20 \mathrm{mM}$ Tris buffer, pH 7.6-10 $\mathrm{mM} \mathrm{KCl}-2 \mathrm{mM} \mathrm{MgCl}_{2}$ at $37^{\circ} \mathrm{C}$ for $60 \mathrm{~min}$ and the ribosomes were recovered by centrifugation at $40,000 \mathrm{rpm}$ for $2 \mathrm{hrs}$.

Estimation of centrifugal pattern of ribosome RNA: The ribosomes treated with reductones were suspended in $0.3 \mathrm{M}$ SDS-50 mM acetate buffer, $\mathrm{pH}$ 5.7-0. $14 \mathrm{M}$ $\mathrm{NaCl}$. The suspension was then mixed with the same volume of $0.1 \% 8$-hydroxyquinolinc-70 \% phenol-10 $\%$ m-cresol-20\% water. The mixture was vigorously shaken at room temperature for $15 \mathrm{~min}$ and centrifuged at $10,000 \mathrm{rpm}$ for $5 \mathrm{~min}$ to separate aqueous layer from phenolic one. The treatment with phenol was samely repeated. To the aqueous layer were added 2 volumes of $2 \%$ potassium acetate-90\% ethanol-10\% m-cresol. The mixture was stirred and stored at $-16^{\circ} \mathrm{C}$ overnight to precipitate RNA. The RNA was collected by centrifugation at $10,000 \mathrm{rpm}$ for $10 \mathrm{~min}$, washed with $95 \%$ ethanol 3 times and dissolved in $50 \mathrm{mM}$ acetate buffer, pH 5.7 .

A $0.2 \mathrm{ml}$-aliquot of the RNA solution $(550 \mu \mathrm{g} / \mathrm{ml})$ were put on the top of the linear gradient of sucrose from $5 \%$ to $20 \%$ in $0.1 \mathrm{M} \mathrm{NaCl}-10 \mathrm{mM}$ acetate buffer, pH 5.1 and centrifuged at 40,000 rpm for $2.5 \mathrm{hrs}$ with a Beckman centrifuge, horizontal type 50-1 rotor. After centrifugal separation, the sample was continuously introduced into a microflow cell by injecting $50 \%$ sucrose carefully from the bottom of the tube with a peristal pump for microtube (Tokyo Rikaki Co.). Then, the absorbance was recorded automatically by estimating at $260 \mathrm{~nm}$ with a spectrophotometer, Hitachi Model 200-10. 


\section{Polysomes}

Preparation of polysomes: Polysomes were prepared by the method of Bloenmendal et al. (1974) from rat liver with a slight modification as follows.

A WKA male rat (about $150 \mathrm{~g}$ body weight), which had been fasted on water for $24 \mathrm{hrs}$, was killed by decaptation. The liver was excised soon and washed with $0.25 \mathrm{M}$ sucrose-TKM buffer. The liver was homogenized with $2.5 \mathrm{ml}$ per $\mathrm{g}$ of the above buffer solution by stroking 8 times of a PotterElvehjem teflon homogenizer. The homogenate was centrifuged at $17,300 \mathrm{rpm}$ for $10 \mathrm{~min}$ and $1 / 3$ of the upper layer of the supernatant was carefully collected by aboiding the contamination of the topmost fatty layer and precipitated fraction of nuclei and mitochondria. To the postmitochondria fraction was added sodium deoxycholate to give the final concentration of $1.3 \%$. The solution was stirred for $30 \mathrm{~min}$ and applied to the top of the double layer of $0.5 \mathrm{M}$ and $2 \mathrm{M}$ sucrose containing TKM buffer set in a nitrate tube for a Beckman ultracentrifuge, L type 30 rotor. The tube was centrifuged at $28,000 \mathrm{rpm}$ for $5 \mathrm{hrs}$ and the clear pellet was obtained. The pellet was then washed with a TKM buffer and suspended in a small volume of the buffer. The suspension was centrifuged at $4,000 \mathrm{rpm}$ for $5 \mathrm{~min}$ to remove undissolved matters. The supernatant was employed as polysome fraction for the study. This fraction showed an absorption maximum at $259 \mathrm{~nm}$ and a minimum at $236 \mathrm{~nm}$. The ratio $\mathrm{E}_{280} / 260$ was 0.53 . Amount of polysomes was expressed as the absorbance at $260 \mathrm{~nm}$ (e. g. $\left.\mathrm{E}_{260} / \mathrm{ml}\right)$.

Treatment of polysomes with reductones and estimation of centrifugal pattern :Polysomes $\left(20 \mathrm{E}_{260} / \mathrm{ml}\right)$ were incubated with $2 \mathrm{mM}$ reductones in $40 \mathrm{mM}$ Tris buffer, $\mathrm{pH} 7.6-20 \mathrm{mM} \mathrm{KCl}-4 \mathrm{mM} \mathrm{MgCl}_{2}$ at $0^{\circ} \mathrm{C}$ for $30 \mathrm{~min}$. They were applied to the sucrose linear gradient from $15 \%$ to $30 \%$ containing TKM buffer and centrifuged at $35,000 \mathrm{rpm}$ for $60 \mathrm{~min}$ with a Beckman ultracentrifuge, horizontal type 50-1 rotor. After centrifugal separation, the absorbancy of the polysomes was estimated automatically with a microflow cell connected with a peristal pump as above.

\section{Protein synthesizing system}

Preparation of $p H 5$ fraction: A pH 5 fraction was prepared from the postmitochondria fraction according to Takanami (1968) as follows.

The postmitochondria fraction prepared as above was centrifuged at $105,000 \times \mathrm{g}$ for $2 \mathrm{hrs}$ to remove microsomes. To upper $2 / 3$ of the clear super. natant was added $1 \mathrm{~N}$ acetic acid under stirring to adjust its $\mathrm{pH}$ to 5.0. The mixture was centrifuged after standing for $5 \mathrm{~min}$. The precipitate was washed with ice-cold deionized water and suspended in a small volume of water. The suspension was dissolved by increasing the $\mathrm{pH}$ value to 8.0 by dropwise addition of $1 \mathrm{~N} \mathrm{KOH}$. Tris buffer, $\mathrm{pH}$ 7. 6, was additionally added to give a final concentration of $50 \mathrm{mM}$. The concentration of protein in the solution was adjusted to about $1 \%$ and used as "pH 5 fraction".

Assay of protein synthesis: Protein synthesis was assayed by estimating the radioactivity of " $\mathrm{C}$-amino acid incorporated into acid-insoluble fraction. Reaction mixture was shown in Table 1 . The system was incubated at $37^{\circ} \mathrm{C}$ for 20 
Table 1. Components of the protein synthsizing system.

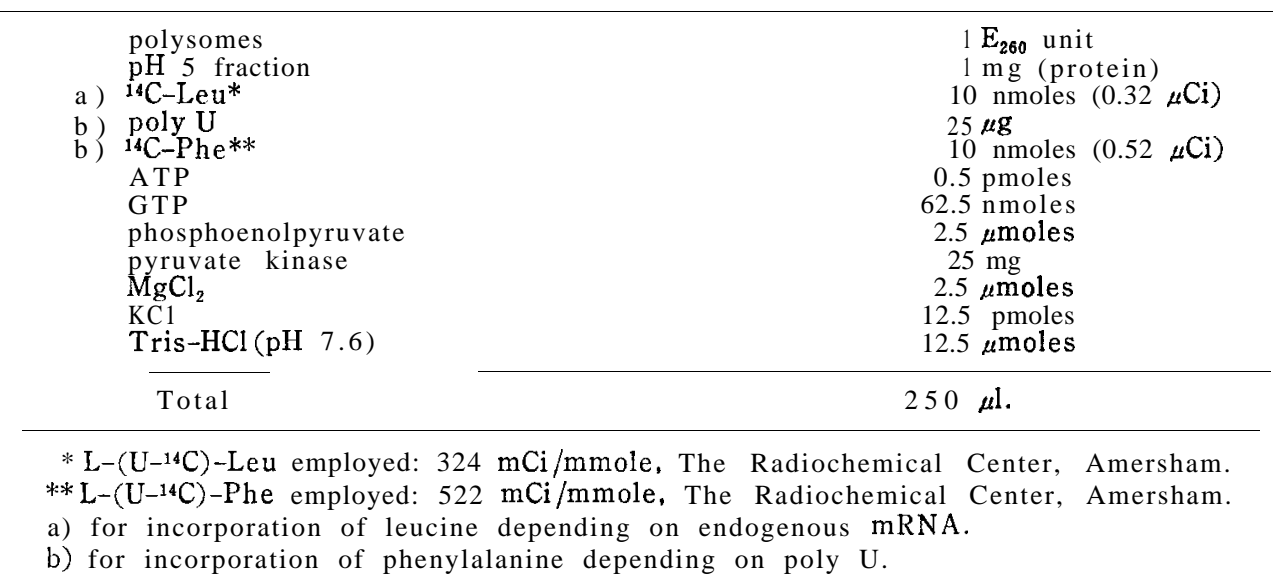

min and cooled with ice to terminate the reaction. Subsequently, it was mixed with $2 \mathrm{ml} 0.5 \mathrm{~N}$ perchloric acid and left for $30 \mathrm{~min}$. Acid-insoluble fraction was collected on glass filter paper (Whatman GF/C), washed twice with $3 \mathrm{ml}$ portion of cold $0.5 \mathrm{~N}$ perchloric acid and dried under an infrared lamp. In the case of incorporation of ${ }^{14} \mathrm{C}$-Phe depending on poly $\mathrm{U}$, the synthesizing system excluded them was preliminary incubated at $37^{\circ} \mathrm{C}$ for $20 \mathrm{~min}$ to remove endogenous mRNA from polysomes. After that, poly $U$ and ${ }^{14} \mathrm{C}-\mathrm{Phe}$ were added to start the reaction. To stop the reaction, $0.5 \mathrm{ml}$ of phenylalanine (2 $\mathrm{mg} / \mathrm{ml}$ ) were first added and then $3 \mathrm{ml}$ cold $0.5 \mathrm{~N}$ perchloric acid. Radioactivity was estimated with a Beckman LS 250 liquid scintillation counter, using 0.49 PPO-67\% Triton X-100-33\% toluene as scintillant. The assay of protein synthesis was carried out duplicatedly and the average value was indicated.

Protein synthesis with liver slice: The test was carried out by the procedure of Gonzalez-Cadavid and Quijáda (1974).

A WKA male rat weighing about $150 \mathrm{~g}$ was killed by decaptation. The liver was rapidly excised, freed from extraneous tissues, washed with $0.9 \%$ $\mathrm{NaCl}\left(20^{\prime \prime}\right.$ to $\left.22^{\circ} \mathrm{C}\right)$ and cut into rectangular pieces $(0.4$ to $0.5 \mathrm{~g})$. They were transferred into $4 \mathrm{ml}$ culture medium A (a mixture containing $95 \mathrm{mM} \mathrm{NaCl}, 10$ $\mathrm{mM} \mathrm{CaCl}_{2}, 10 \mathrm{mM} \mathrm{KC} 1$ and $40 \mathrm{mM} \mathrm{NaHCO}_{3}$ was preliminary passed with $5 \% \mathrm{CO}_{2}$ $-95 \%$ air and was then supplemented with $20 \mathrm{mM}$ glucose just before using).

The liver slices in the culture medium A were kept at $37^{\circ} \mathrm{C}$ in an incubator containing $5 \% \mathrm{CO}_{2}-95 \%$ air. The slices were contacted with $0.5 \mathrm{mM}$ reductones for $30 \mathrm{~min}$, followed with $25 \mu \mathrm{Ci}$ " $\mathrm{C}$-amino acid mixture $\left(\left[\mathrm{U}-{ }^{14} \mathrm{C}\right]\right.$ prntein hydrolysate) for $60 \mathrm{~min}$. Afer the reaction, the slices were put into ice-cold water and freed from the culture medium by centrifugation at 1,000 rpm for $5 \mathrm{~min}$. The slices were homogenized in $0.3 \mathrm{M}$ sucrose with a teflon homogenizer and centrifuged at $6,000 \mathrm{rpm}$ for $10 \mathrm{~min}$ to remove cell debris. The cell extract was further centrifuded at $13,000 \mathrm{rpm}$ for $10 \mathrm{~min}$. The supernatant, postmitochondria fraction, was centrifuged at $28,000 \mathrm{rpm}$ for $150 \mathrm{~min}$ 
to precipitate the microsome fraction. The pellet was dissolved in $0.25 \mathrm{M}$ SDS-50 mM NaCl-5 mM Tris buffer, pH 7.4-O. 5 mM EDTA. An 0. 5 ml-aliquot of the solution was mixed with $10 \mathrm{ml} \mathrm{0.4 \%} \mathrm{PPO-67 \%} \mathrm{Triton} \mathrm{X-100-33} \mathrm{\%}$ toluene and the radioactivity was estimated with a Beckman LS 250 liquid scintillator. Protein content of the solution was also samely determined by Lowry's me- thod (Lowry et al., 1951).

\section{RESULTS}

\section{Breakage of RNA by treating ribosomes with reductones}

Degradation of RNA as well as DNA with reductones was confimed mostly in vitro, especially using the purely extracted nucleic acids. Their breaking ability must be further established, although degradation of chromosomal DNA was observed in cultured mammalian cells, RFL and HeLa, even with aroma-

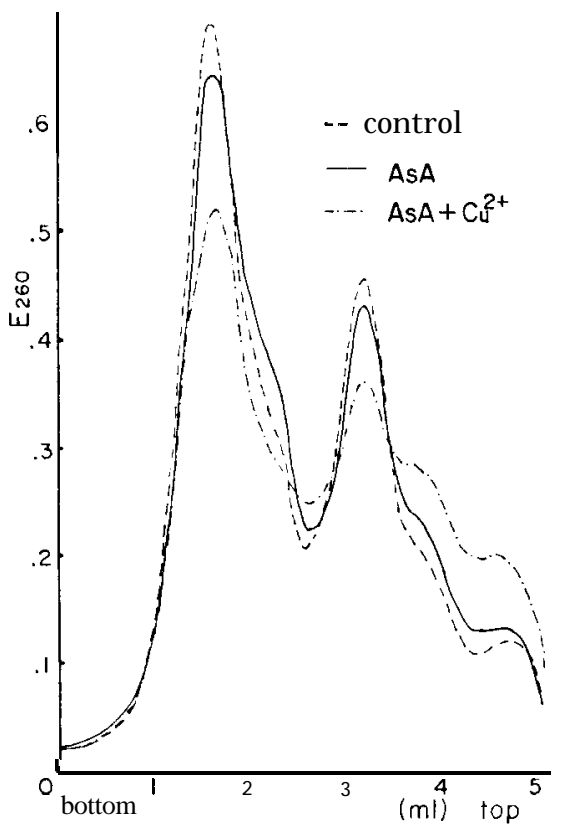

Fig. 1. Sedimentation pattern of rRNA from ribosomes treated with AsA. Ribosomes $(2 \mathrm{mg} / \mathrm{ml})$ were treated with $5 \mathrm{mMAsA}$ with or without $50 \mu \mathrm{M} \mathrm{Cu}^{2+}$ at $37^{\circ} \mathrm{C}$ for $1 \mathrm{hr}$. After extracting rRNA from the ribosome, the RNA was subjected to the sucrose density gradient centrifugal analysis $(5 \%-20 \%)$.

tic reductones such as epinephrine, norepinephrine and their derivatives (Murakami et al., 1975, 1978a, b). On the other hand, it was demonstrated that crude DNA preparation containing much protein was more resistant than the purified DNA against the action of reductones, using some amino reductones, 


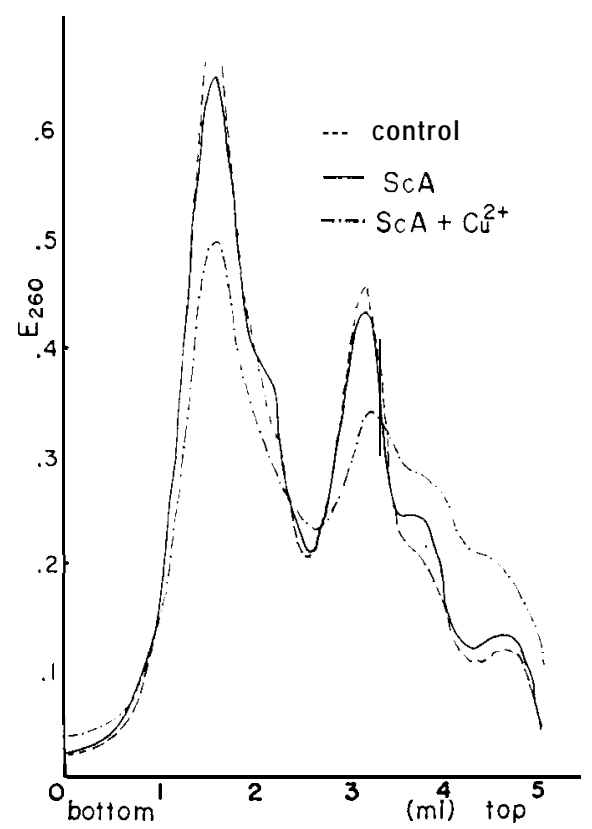

Fig. 2. Sedimentation pattern of rRNA from ribosomes treated with ScA. The same as in Fig. 1.

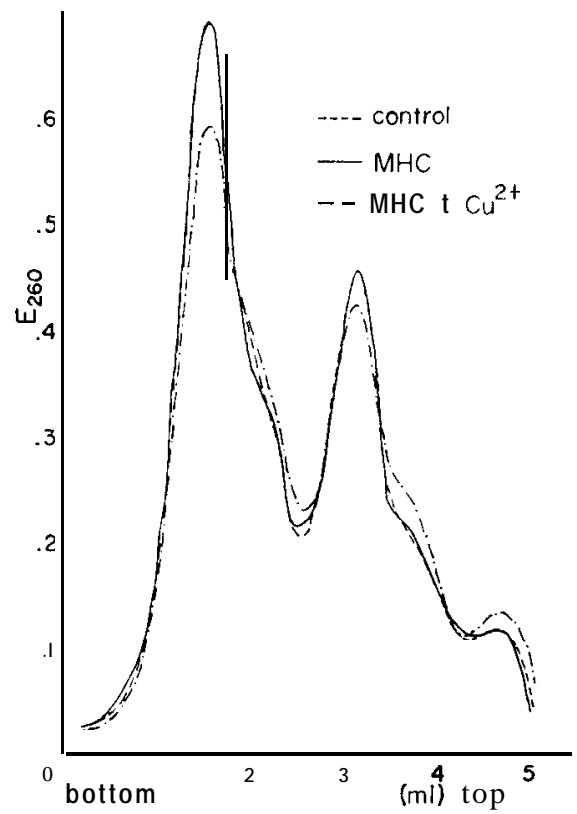

Fig. 3. Sedimentation pattern of rRNA from ribosomes treated with MHC. The same as in Fig. 1. 
3-hydroxykynurenine and 3-hydroxyanthranilic acid which are carcinogenic metabolites of tryptophan (Fujii et al., 1972). In ribosomes, RNA seems to be coated and/ or mingled with ribosomal protein. Therefore, the susceptibility of ribosomal RNA to reductones should be examined in order to estimate some variation of ribosomal functions after treatment with them, if occur. Ribosomes were treated with $5 \mathrm{mMAsA}, \mathrm{ScA}$ or MHC with or without $50 \mu \mathrm{M}$ $\mathrm{Cu}^{2+}$ at $37^{\circ} \mathrm{C}$ for $60 \mathrm{~min}$. Ribosomal RNA was extracted from them and examined by the sucrose density gradient centrifugation. The patterns are shown in Figs. I-3. It was thus confirmed that all reductones examined, i.e. enediol-, enaminol- and thiolenol-reductones, are able to break rRNA even in the ribosome particles, similar to their action on the pure RNA preparation in vitro. In the case of the reductone alone, both the main fractions of rRNA, $28 \mathrm{~S}$ and $18 \mathrm{~S}$, were degraded a little by AsA and ScA, but not by $\mathrm{MHC}$. However, $\mathrm{Cu}^{2+}$ accelerated the action and higher degradations were observed not only by AsA and $\mathrm{ScA}$, but also by $\mathrm{MHC}$.

\section{Action of reductones on polysomes}

Polysomes take an important part in protein synthesis, in which RNA occupies the central part, especially translation of information in DNA.

Polysomes are separable according to the degree of polymerization by means of the sucrose density gradient centrifugation. Isolated polysomes were treated with $2 \mathrm{mM}$ reductone at $0^{\circ} \mathrm{C}$ for $30 \mathrm{~min}$ and examined their variation of the sedimentation pattern. Since $\mathrm{Cu}^{2+}$ disturbed the pattern, the reductones were treated only in the absence of $\mathrm{Cu}^{2+}$. The results are shown in Figs. 4-8.

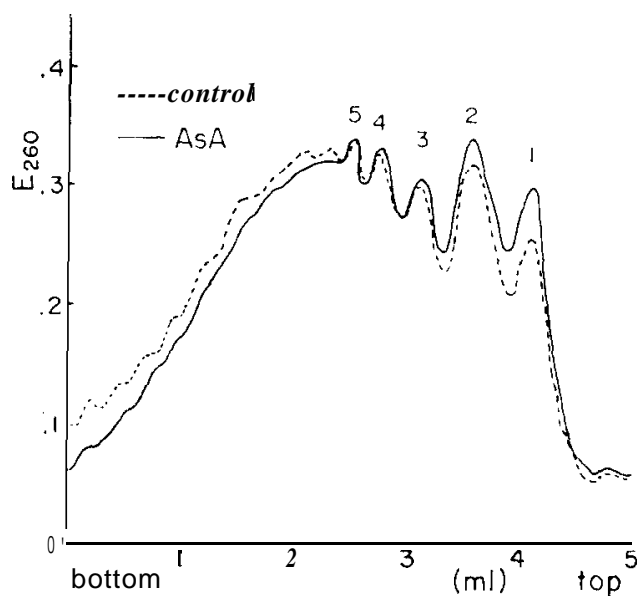

Fig. 4. Degradation of polysomes by AsA. Polysomes $\left(20 \mathrm{E}_{260}\right.$ units $\left./ \mathrm{ml}\right)$ were treated with $2 \mathrm{mM} \mathrm{AsA}$ at $0^{\circ} \mathrm{C}$ for $30 \mathrm{~min}$ and applied to the sucrose density gradient centrifugal analysis (15 $\%$-30\%).

AsA, MDT and ScA caused some decrease of fractions of higher degree of polymerization more than pentamer and increase of monomer and dimer. 


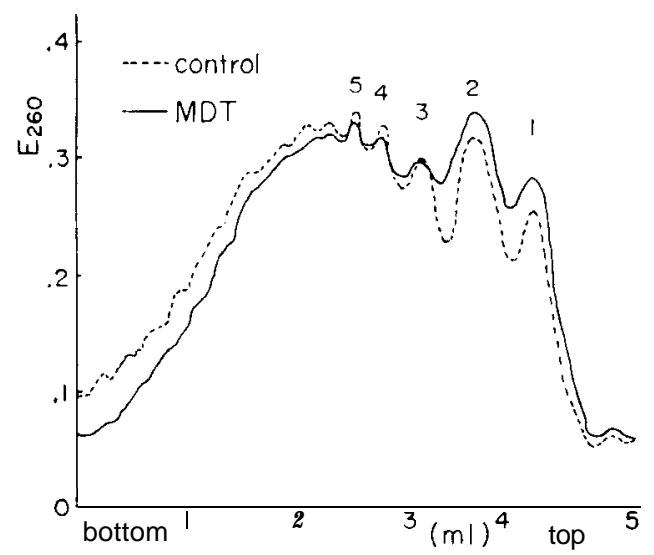

Fig. 5. Degradation of polysomes by MDT. The same as in Fig. 4.

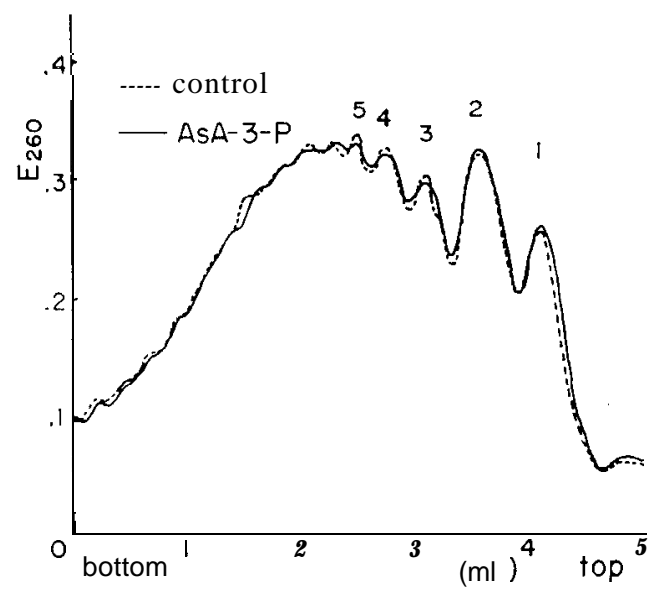

Fig. 6. Sedimentation pattern of polysomes treated with AsA-3-P. The same as in Fig. 4.

The similar variation was observed with MHC, while not so remarkable. However, AsA-3-P had no effect on polysomes, suggesting the importance of the reductonic group in the molecule as case of the breakage of nucleic acids.

\section{Effect of reductones on the protein synthesis}

In order to estimate the effect of reductones on the protein synthesis, the incorporation of ${ }^{14} \mathrm{C}$-amino acid was first assayed using the system of the polysomes and the pH 5 fraction in the presence of $0.1 \mathrm{mM}$ recdutone at $37^{\circ} \mathrm{C}$ for $20 \mathrm{~min}$. The assay was carried out duplicatedly and the average value was indicated. In the case of ${ }^{14} \mathrm{C}-\mathrm{Leu}$, the incorporation was estimated depending on the endogenous mRNA in the system. The result is shown in Table 2. The incorporation was retarded to $77 \%$ with AsA, $62 \%$ with MD T, 


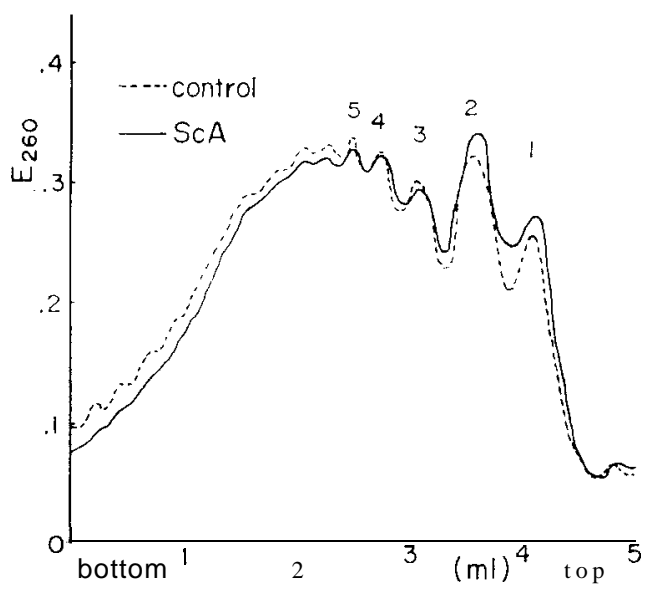

Fig. 7. Degradation of polysomes by ScA. The same as in Fig. 4.

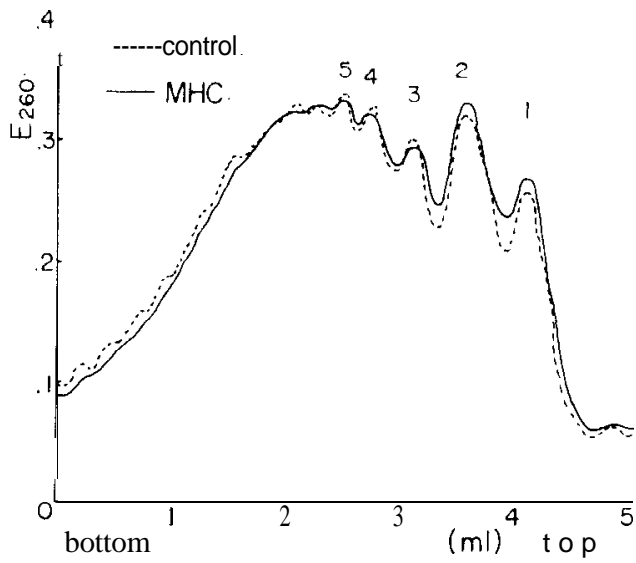

Fig. 8. Degradation of polysomes by MHC. The same as in Fig. 4

'Table 2. Effect of reductones on the protein synthesis depending on endogenous mRNA.

\begin{tabular}{l} 
Reductones \\
\hline Control \\
AsA \\
MDT \\
ScA \\
MHC
\end{tabular}

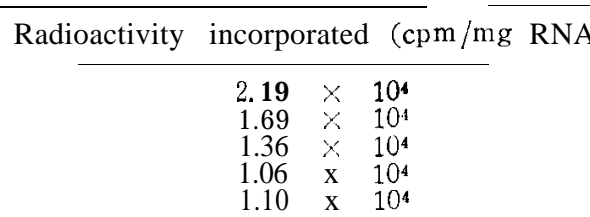

\begin{tabular}{r}
\hline$\%)$ \\
100 \\
77 \\
62 \\
49 \\
50
\end{tabular}

49\% with ScA and 50\% with MHC. As shown in Table 3, similar effect of reductones was observed regarding the incorporation of ${ }^{14} \mathrm{C}$-Phe depending on poly $U$ as the messenger in place of the endogenous mRNA. In this case too, the decrease of the incorporation was brought about. By the action of AsA, 
Table 3. Effect of reductones on the protein syhthesis depending on poly U.

Reductones
Control
AsA
MD'1
ScA
MHC

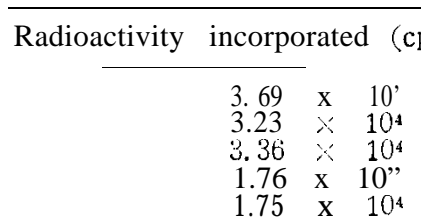

the rate was repressed to $87 \%$, to $91 \%$ by MDT, to $48 \%$ by $\mathrm{ScA}$ and to $47 \%$ by MHC. Finally, the protein synthesis was estimated using liver slices with $0.5 \mathrm{mM}$ reductone at $37^{\circ} \mathrm{C}$ for $20 \mathrm{~min}$. The assays were conducted independently 3 times and the average values of the incorporation of ' $Y$-protein hydrolysate are shown in Table 4. A weak repression of about 15 to 20 was observed with AsA, MDT or ScA, but not with AsA-3-P or MHC. Thus, the retardation of the protein synthesis in the polysomes and the $\mathrm{pH} 5$ fraction was induced by the enaminol and thiolenol, although that was not so much by the enediol. On the other hand, compared with this system, the effect of the enediol and enaminol on the liver slices were relatively weak and that of $\mathrm{MHC}$ and AsA-3-P was not significant.

Table 4. Effect of reductones on the protein synthesis in liver slices.

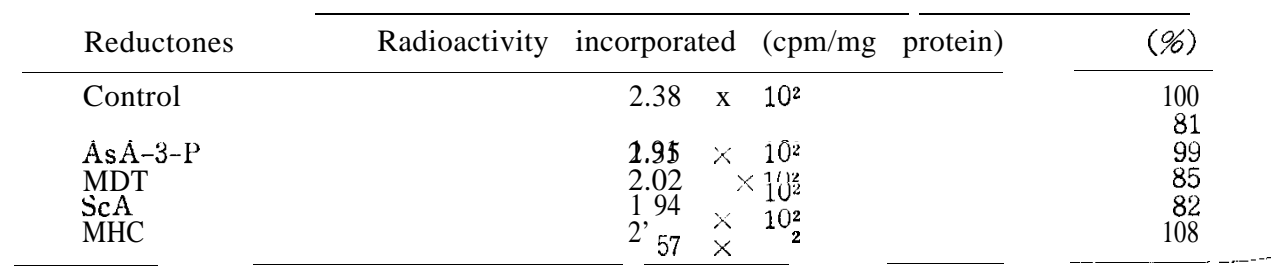

\section{DISCUSSION}

In the case of the purified RNA preparation, the ribosomal RNA was also breaked in the particle by the action of reductones, although to less extent. On the other hand, even by the mild treatment of them at $0^{\circ} \mathrm{C}$, the sedimentation profile of the polysome was altered with inducing increase of the lower fractions and decrease of the higher ones. A similar phenomenon was observcd when the polysome had been prepared with vigorous procedure or treated with ribonuclease (Wettstein et al., 1963). The variation might be attributed to the scission of mRNA connecting the ribosomes by the reductones. However, as often observed, AsA-3-P had not the ability and the breaking degree of the enediol (AsA, MDT) or the enaminol ( $\mathrm{ScA}$ ) was higher than that of the thiolenol (MHC). These observations indicate that the reductone structure is indispensable for the breakage of the nucleic acids and that the activity is dependent on the kind of them.

The information in DNA is transferred to protein through transcription 
and translation, in which mRNA takes an important part. Although role of rRNA is not clarified, some one such as a mere framework mingled or covered with protein might be presumed. Therefore, the damage of mRNA as well as rRNA, if occurred in the polysomes and ribosomes, may cause not only the structural but also the functional variation of the polysomes. In addition, it was shown that the priming activity for the RNA polymerase was brought about by degradation of the template DNA with reductones. This might change the amounts of RNA formed too. These variations might affect on protein synthesis. Actually, the incorporation of amino acids into protein in the protein synthesizing system of the polysome and $\mathrm{pH} 5$ enzyme with endogenous RNA or poly $U$ was inhibited by the reductones. Contrary to the breaking ability on nucleic acids, however, the inhibiting effect was remarkable with the enaminol and the thiolenol. Furthermore, the incorporation of amino acids into rat liver slices was also slightly repressed by the enediol and the enaminol. The discrepancy between the liver slices and the polysome system is complicated, but may be interpreted as being due to some barriers of the metabolisms or permeability in liver slices, for example. At any rate, the results obtained might indicate that all reductones examined affect on the protein synthesis, probably through the degradation of nucleic acids.

On the basis of the many systematical researches in our Institute, Yamafuji et al. (1970a, 1971) presented a hypothesis, the Yamafuji's effect, which demonstrates that a suitable scission of chromosomal DNA should be an initiating step in several fundamental biological functions such as cytodifferentiation and cytoanomalization. These phenomena include antibody formation, brain function, hormonal action, mutagenesis, carcinogenesis, carcinostasis and virogenesis. Some of them was confirmed with reductones. However, steps between DNA breakage and these biological phenomena had been remained to be elucidated. Thus, studies carried out along the central dogma provided some clues. Variation of the priming activity was provoked by the action of reductones on the template DNA for DNA and RNA polymerases, which was attributed to the degradation of DNA. This variation might induce the qualitative and quantitative changes of nucleic acids formed. In addition, since RNA in ribosome and polysome was breaked by the action of reductones, protein synthesis was also influenced. Thus, the results may give an additional support to the Yamafuji's effect.

This work was partly supported by a Grant-in-Aid for Scientific Research from the Ministry of Education, Science and Culture, the Goverment of Japan (Grant No. 247106).

\section{REFERENCES}

Bloemendal, H., E. L. Benedetti and W. S. Bont 1974 Preparation and characterization of free and membrane-bound polysomes. In "Methods in Enzymology," Vol. 30, ed. by K. Moldave and L. Grossman, Academic Press, Inc., New York, pp. 313-327

Fujii, T., K. Yamafuji and H. Omura 1972 Effect of 3-hydroxykynurenine and 3-hydroxyanthranilic acid on RNA polymerase. Eiyo to Shokuryo (J. Jap.Soc. Food and Nutrition). 


\section{5: 309}

Gonzalez-Cadavid. N. F. and F. H. Quijáda 1974 Inhibition of translation in liver polyribosomes by a new substituted thiopseudourea with antitumour action. Biochem. J., 138: 129-141

Lowry, 0. H., N. J. Rosebrough, A. L. Farr and R. J. Randall 1951 Protein measurement with the Folin phenol reagent. J.Biol. Chem.. 193: 265-275

Murakami. H., T. Miyoshi, M. Koga, K. Yamada and H. Omura 1975 Breakage of chromosomal DNA with aromatic reductones. Agr. Biol. Chem., 39: 795-801

Murakami, H., K. Yamada, S. Shirahata, H. Nishiguchi, K. Shinohara and H. Omura 1978a Double strand breakage of chromatin DNA in cultured mammalian cells and DNA extracted from $\lambda$ phage by aromatic reductones derived from adrenalone. Agr. Biol. Chem.. 42 : 1019-1023

Murakami, H., K. Yamada, S. Shirahata. K. Shinohara and H. Omura 1978b Intranuclear incorporation and binding to chromosomal DNA of epinephrine. Agr. Biol. Chem., 42: 45-48

Muramatsu. M. 1972 Ribosome RNA in animal cells. Tanpakushitsu, Kakusan, Koso (Protein. Nucleic acid, Enzyme), Sp. Vol. "Method in nucleic acid research (A)“, Kyoritsu Shuppan, Tokyo, pp. 35-38

Omura, H., Y. Fukumoto, Y. Tomita and K. Shinohara 1975 Action of 5-methyl-3, 4-dihydroxytetrone on deoxyribonucleic acid. J.Fac. Agr., Kyushu Univ., 19: 139-148

Omura, H., K. Shinohara, H. Maeda, M. Nonaka and H. Murakami 1978 Mutagenic action of triose reductone and ascorbic acid on Salmonella typhimurium TA 100 strain. J.Nutr. Sci. Vitaminol., 24: 185-194

Omura, H., Y. Tomita, Y. Nakamura and H. Murakami 1974 Antitumoric patentiality of some ascorbate derivatives. J. Fac. Agr. Kyushu Univ., 18: 181-189

Takanami. M. 1968 Methods for preparation of ribosome and s-RNA-mainly from animal cells. Kakusan Jikken Ho (Method in nucleic acid research), Kyoritsu Shuppan. Tokyo, pp. 76-86

Tomita, Y., H Fujki,K. Shinohara, H. Murakami and H. Omura 1979 Effect of some reductones on DNA and RNA polymerases. J. Fac. Agr., Kyushu Univ., 24: 21-36

Wettstein, F. O., T. Staehlin and H. Noll 1963 Ribosomal aggregate engaged in protein synthesis : characterization of the ergosome. Nature, $197:$ 430-435

Yamafuji, K. 1970 Food, cancer and cytodifferentiation. Shukosha, Fukuoka, Japan

Yamafuji, K. and H. Murakami 1968 Antitumour potency of lignin and pyrocatechol and their action on deoxyribonucleic acid. Enzymologia, 35: 139-153

Yamafuji, K., H. Murakami and M. Shinozuka 1970 Antitumor activity of Dopa, Dopamine. noradrenalin or adrenalin and their reaction with nucleic acids. $Z$. Krebsforsch., 73: 195-203

Yamafuji, K., Y. Nakamura, H. Omura. T. Soeda and K. Gyotoku 1971a Antitumour potency of ascorbic, dehydroascorbic or 2. 3-diketogulonic acid and their action on deoxyribonucleic acid. Z.Krebsforsch., 76: 1-7

Yamafuji, K., K. Shinohara, F. Yoshihara, M. Iio and Y. Torikai 1971b Breakage of nucleic acids as initiative process of cytodifferentiation and cytoanomalization. Enzymologia, 40 : 107-119 